\title{
Saudação ao Professor Fernando Emydio da Silva da Universidade de Lisboa (*)
}

\author{
J. J. Cardozo de Melo Neto
}

Recordar é viver. Principalmente para os homens que, concientes da origem divina da creatura, organizam o presente - olhos fitos no passado, dele herdando a soma de ensinamentos, a vocação do desprendimento, o acêrvo de dignidade, - únicos fatores do progresso humano, quando ele quer ser a civilização cristã, e não simplesmente o aumento de bens e gôzo material da vida.

Recordar é viver. Não, unicamente, numa atitude estática ou passiva, mas para aprender, para orientar a vida numa direção retilínea, não se perdendo jamais nos atalhos do caminho, nem nos detalhes do trabalho, pelo conhecimento adquirido das experiências, dos desvios, dos sofrimentos de nossos antepassados.

Recordar é viver. Nesta Casa, que é a Casa do Direito no Brasil, e, como tal, a guarda da tradição jurídica que liga o presente ao passado, dando um sentido ao futuro.

Recordar é viver. Sobretudo em presença de um lidimo representante da formação espiritual da gente portuguesa cuja vóz chega aos nossos ouvidos no tom inconfundivel da vóz de família.

Recordar é viver.

(*) Proferida, em nome da Congregação da Faculdade de Direito da Universidade de São Paulo, na sessão solene de recepção realizada, em 27 de novembro de 1939, na sala "João Mendes" 
Ha quatorze anos feitos, uma turma de estudantes de Coimbra que, como a manto diáfano da música, escondiam a realidade da propagação do ideal de fraternidade e solidariedade humanas, visitava S. Paulo, e era por nós recebida de uma maneira excepcional. Basta abrir um dos jornais da época - "O Jornal do Comércio" — de 25 de agosto de 1925, para evidenciá-lo. A todas as festas, excedeu, porẻm, a realizada nesta Faculdade. "Notava-se tudo que $\mathrm{S}$. Paulo tem de distinto, elegante e ilustre. Estudantes de todas as escolas, professores, advogados, políticos, jornalistas e exmas. famílias de nossa élite social" "Por entre alas dos assistentes passaram os estudantes coimbrenses, saudados com salvas de palmas" Presidindo á reunião, falou Reynaldo Porchat evocando, com aquele fulgor inconfundivel que é uma gloria nossa, a tradicional Coimbra, de onde vieram os primeiros lentes, a fórma dos átos, o doutoral, as bécas, que ainda hoje nos revestem. E, a cima de tudo, a alma portuguesa. E por ultimo, em nome da Congregação dos Professores, aquele mesmo que, nesta qualidade ainda, vos dirige a palavra, sr. prof. Emydio da Silva.

Agora, quatorze anos passados, é a um alto representante dos formadores da mentalidade dos moços de Portugal que nos dirigimos, para agradecer, desvanecidos, a bela mensagem de saudação da Universidade de Lisbôa.

Bem andaram aqueles que tiveram a ideia desse documento de cordialidade. Hoje, mais do que nunca, é preciso ligar os homens pelo ideal.

"Em verdade, qual o espetáculo do mundo", perguntava eu em 1925 ?

"O homem esquecido di? que nasce devedor à sociedade do conjunto de benefícios que lhe assegura a civilização, fruto do trabalho das gerações anteriores, não cuida de pagar essa dívida contraída com o passado, pelo aumento do patrimônio moral que a sociedade atual deve transmitir à futura. E, ao contrário, sedenta do sangue amarelo 
que jorra das minas de ouro, como féra procede. Tudo se resume na caça do ouro, porque só o ouro dá o bem estar material - unico de que o homem cuida insulado no seu materialismo egoístico. E' o retôrno ao artificial sistema mercantil, que precedeu ao reconhecimento de uma ordem natural e essencial das sociedades humanas, da qual únicamente póde surgir a harmonia dos interesses. E', o que dantes não era, a sêde de ouro ultrapassando do círculo econômico para dominar todas as relações morais. Hoje, mais do que nunca, Bresson teria razão: - o bem não é senão o util, o mal o obstaculo ás paixões; não ha senão apetites, as palavras perderam sua significação habitual, modificam-se as opiniões ao sabor das circunstancias e as mais vergonhosas apostasias recebem qualificativos de opiniões sucessivas, ou de mudança de atitude"

Será diferente, para melhor, ou para piór, o espetáculo atual do mundo?

Vós, snr. Professor, estais perfeitamente aparelhado para opinar em assunto assim vital para a civilização.

Ha vinte e cinco anos, ainda em plena éra individualista, não vos sorria o Estado indiferente. Abrindo o capitulo da "Formação da teoria do risco profissional", em vossa tése de concurso sobre "Acidentes do trabalho", dizíeis, definindo uma orientação segura, mas singular para a época:

"O espírito com que as questões de trabalho têm sido estudadas possúe, quanto a nós, primariamente, o mérito de as perscrutar antes de tudo na sua existência real e normal. O que produziu desde logo o resultado maravilhoso de encarar, numa só desconfiança as grandes máximas libe- 
rais de Economia Política e do direito de Revolução - segundo as quais um Estado indiferente proclama uma igualdade nominal e sancionava uma especulação abusiva derivada das desigualdades de fato dos pactuantes - mas de rejeitar com escândalo - e no campo jurídico algumas das velharias promovidas por antiguidade a dogmas intangíveis e clássicos da sociedade e do Direito“.

Professor de Ciência das Finanças, sois, de ha muito, tambem, vice-governador do Banco de Portugal. Alia-se, assim, à ciência a arte financeira, num trato diuturno com os mais complexos fenomenos político-sociais do presente momento, em que ao homem se depara uma encruzilhada: - ou tomar a direita, para procurar reconstruir a estrada que as enxurradas já fizeram perder o nivel, ou deixar-se conduzir à esquerda para o abismo onde ficará, para sempre, sepultado aquele acêrvo de civilização cristã, ao começo deste referido.

$\mathrm{Ou}$, recordar para viver. Ou esquecermo-nos de nós mesmos, para desaparecer.

Nada mais apropriado para orientar governantes e governados no caminho da direita do que entre outros o conhecimento da disciplina que ensinais.

Nela, confere-se ao administrador os meios de desenvolver a atividade do Estado, progressivamente crescente pela soma de serviços que, à benefício geral, lhe vão ficando a cargo.

Tudo, porém, dentro daquele ótimo meio termo entre o dever do Estado de coordenar e dirigir e o direito inalienavel da personalidade humana de pensar e agir, por si.

A orientação de vosso espírito ficou patente desde vossa dissertação inicial quando, em matéria de trabalho, doutrináveis :

"O Estado indiferente justificou o aparecimento de toda essa corrente doutrinal e legislativa 
de proteção e respeito pela vida operária que a economia e o direito clássicos se não cansam de apelidar uma "exceção" e um "privilégio", quando a não taxam de uma revolução, e que, afinal, não passa da necessidade em que o legislador se viu, estudadas especialmente as relações entre patrões e operários (que são a base da produção) de garantir direitos indeclinaveis a quem dessa garantia necessitava e pelo modo por que essa garantia se não tornasse num aparato e lôgro decorativos"

Bela cousa o ensino assim orientado. Missão mais alta não ha do que professar com esse espírito. Dentro dele, snr. professor Fernando Emydio da Silva, a Congregação dos Professores da Faculdade de Direito de S. Paulo vos saúda, e à Universidade de Lisbôa, que tão dignamente representais. 